\title{
Social Stigma toward Health Workers Associated with Coronavirus Disease 2019
}

\author{
Muhammad Faris, Muhammad Reza Arifianto* \\ Department of Neurosurgery, Dr. Soetomo Academic General Hospital, Faculty of Medicine - Airlangga University, Surabaya, \\ Indonesia
}

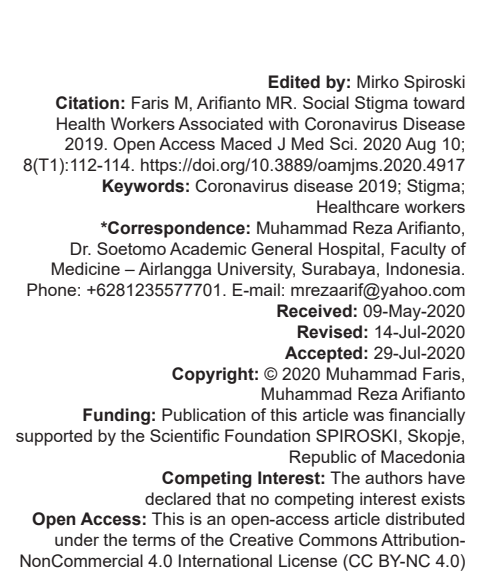

\section{Introduction}

Stigma is a powerful social process that is characterized by labelling, stereotyping, and separation, leading to loss of status and discrimination, all occurring in the context of power [1]. Stigma also impacts the well-being of the health workforce because healthcare workers may also be living with stigmatized conditions [2]. They may conceal their own health status from colleagues and be reluctant to access and engage in care. Yet, stigma reduction is not a routine part of the way in which health services are delivered or evaluated, nor is it regularly integrated into pre-service and in-service training of all cadres of healthcare workers [3].

Since the end of December 2019, the Chinese city of Wuhan has reported a novel pneumonia caused by coronavirus disease 2019 (COVID-19), which is spreading domestically and internationally [4]. The virus has been named severe acute respiratory syndrome coronavirus 2 [5]. In this report, we will refer to the disease, COVID-19. On January 30, 2020, the World Health Organization (WHO) held an emergency meeting and declared the global COVID-19 outbreak a public health emergency of international concern [6]. Moreover, On March 11, 2020, the WHO declared the novel COVID-19 a global pandemic, which classifies the outbreak as an international emergency [7].

At the time of drafting this editorial, COVID-19 has swept through more than 181 countries, which it means almost all of countries in the world, infected more with around 1,084,000 infected subjects, more than 58,000 death over the world [8]. This disease has been confirmed as the first pandemic in modern days, especially in $21^{\text {st }}$ century.

Facing this critical situation, healthcare workers on the front line who are directly involved in the diagnosis, treatment, and care of patients with COVID19 are at risk of being stigmatized. This correspondence article explores how stigma is currently being addressed in health facilities across medical conditions, discusses gaps arising from a scan of the literature, and the potential for synergies across disease stigmas that could be harnessed for a joint response to more than one disease stigma. Such stigma may be experienced in all spheres of life; however, stigma in health facilities is particularly egregious, negatively affecting people seeking health services at a time when they are at their most vulnerable. 
Synergy is needed for stigma reduction although it needs some effort in large scale and cost and time consuming. However, clearly, interventions must pay attention to specific cultural and socioeconomic contexts and recognize that stigmas are not always experienced in the same way in all settings. An improved understanding of how health condition stigma is currently addressed in health facilities is needed to identify gaps and areas for investment in stigma reduction, as well as to explore the possibility of concurrently addressing more than one health condition stigma with a joint intervention. Thus, this correspondence article takes an explicitly programmatic focus and aims to examine "how" health facility-based stigma reduction interventions are implemented across health condition stigmas.

From social media, it can be seen that support for health workers during the outbreak of the COVID19 pandemic is huge [9]. This support came from many parties, ranging from ordinary people, community leaders, government officials, artists, musicians, and even to social organizations and businesses. This form of support is also very diverse. This form of support is also very diverse, starting from messages of support, songs, poems, incentives for health workers, to the provision of free food and drinks from businesses and the community. Donations from ordinary people in the form of personal protective equipment and various other needs needed by medical personnel during the pandemic [10].

The messages that have emerged on social media and the mainstream illustrates that health workers are heroes who are struggling on the front lines in the face of this pandemic. They are described as willing to struggle to risk their lives to save others in a pandemic. This large number of messages and real support illustrates that there is a strong positive stigma for health workers in our society. Of course this is very encouraging.

But that does not mean that there is no negative stigma for health workers working in this pandemic situation. Negative stigma as a person who brings disease appears in the community. Although from the news and information that appeared in the media it can be concluded that most of this stigma occurs in people with low education in rural areas whose access to information is still limited, but this also still occurs in the republic's capital and in front of one of the main referral hospitals for cases COVID-19 in Indonesia, too [11]. People were afraid that medical workers could be at risk of transmitting the virus. Unable to find other places to stay, some medical workers had to stay at the hospital [9].

Even after this news went viral and drew public criticism, it seemed that the stigmatization of the medical staff also did not stop spontaneously. Resident doctors also were at risk. Society tends to discriminate on the grounds of notification from the local government to avoid contact with people suspected of being exposed to the virus in the hospital [12]. The same situation is experienced by health workers in several other regions in Indonesia, although the news is not massive. Mostly, doctors who got stigmatized working on large hospital which is the referral center for respiratory disease and other infectious disease in Indonesia. Even though in the end of the two cases above, the government has intervened, even giving a legal assistance, but this indicates that stigmatization of health workers during the pandemic has not diminished. Stigma is associated being unreasonable fear with infectious disease can be a barrier to adopting healthy behaviors, leading to difficulty controlling infectious disease outbreaks [13].

The government itself has actually promoted socialization about COVID-19, including the importance of mutual support and assistance including morally and psychosocially for the sufferers and health workers involved. This message from the government was included in one of the mental and psychosocial health campaigns launched by the WHO to deal with the COVID-19 pandemic. However, negative stigma for health workers and patients and their families suffering from COVID-19 remains strongly attached. Of course we do not forget cases of rejection of patients and their families in several boarding houses near the hospital where patients were treated, even the refusal to bury COVID-19 patients in various areas that had been viral [14]. The Indonesian government, to this day, continues to face public pressure, even from the central legislature, to promote socialization and make regulations to prevent stigmatization of patients and medical workers affected by COVID-19 so as not to experience the events above. But until now, unfortunately, there is no specific regulation from the government to deal with the complicated situation for health workers. Even so, the government, both central and regional, still continues to try to disseminate information to reduce this stigmatization, even though it is still considered to be not optimal [14], [15].

This is a chore for all of us, not just the government. Synergy between the central government, regional governments, community leaders, and referral hospital officials is certainly important to overcome this stigma problem, in addition to promoting education in the community. Many sources of how to prevent stigma in patients and health workers related to COVID-19 have been published, both by the private sector, government, and even from WHO that we can apply to contribute to changing this condition. Surely, we do not want that in the midst of the struggles of health workers on the front lines with (still) limited means, negative stigma is also attached to them and aggravating their working conditions. 


\section{References}

1. Link BG, Phelan JC. Conceptualizing stigma. Annu Rev Soc 2001;27:363-85. https://doi.org/10.1146/annurev.soc.27.1.363

2. Nyblade L, Stockton MA, Giger K, Bond V, Ekstrand ML, Mc Lean $\mathrm{R}$, et al. Stigma in health facilities: Why it matters and how we can change it. BMC Med. 2019;17:25.

PMid:30764806

3. Nyblade L, Stangl A, Weiss E, Ashburn K. Combating HIV stigma in health care settings: What works? J Int AIDS Soc. 2009;12:15. https://doi.org/10.1186/1758-2652-12-15 PMid:19660113

4. Zhu N, Zhang D, Wang W, Li X, Yang B, Song J, et al. A novel coronavirus from patients with pneumonia in China, 2019. N Engl J Med. 2020;382:727-33.

5. Shereen MA, Khan S, Kazmi A, Bashir N, Siddique R. COVID-19 infection: origin, transmission, and characteristics of human coronaviruses. J Adv Res. 2020;24:91-8. https://doi. org/10.1016/j.jare.2020.03.005

6. Statement on the Second Meeting of the International Health Regulations. Emergency Committee Regarding the Outbreak of Novel Coronavirus (2019-nCoV); 2005. Available from: https://www.who.int/news-room/detail/30-01-2020-statementon-the-second-meeting-of-the-international-health-regulations(2005)-emergency-committee-regarding-the-outbreak-of-novel-coronavirus-(2019-ncov). [Last accessed on 2020 Jul 14]. https://doi.org/10.4178/epih.e2020013

7. World Health Organization. WHO Director-General's Opening Remarks at the Media Briefing on COVID-19 11 March 2020. Available from: https://www.who.int/dg/speeches/detail/whodirector-general-s-opening-remarks-at-the-media-briefing-oncovid-19---11-march-2020. [Last accessed on 2020 Jul 14]. https://doi.org/10.1093/ww/9780199540884.013.u20123

8. Mas-Coma S, Jones MK, Marty AM. COVID-19 and globalization. One Health 2020;9:100132. https://doi.org/10.1016/j. onehlt.2020.100132

9. UNESCO. COVID-19-Related Discrimination and Stigma: A Global Phenomenon? Available from: https://www.en.unesco. org/news/covid-19-related-discrimination-and-stigma-globalphenomenon. [Last accessed on 2020 Jul 14]. https://doi. org/10.31234/osf.io/qpbj7

10. Hou T, Zhang T, Cai W, Song X, Chen A, Deng G, et al. Social support and mental health among health care workers during coronavirus disease 2019 outbreak: A moderated mediation model. PLoS One 2020;15:e0233831. https://doi.org/10.1371/ journal.pone.0233831

11. Atika S. Stigma, Precarity Deter Indonesians from Getting Tested for COVID-19 National the Jakarta Post. Available from: https://www.thejakartapost.com/news/2020/07/08/stigmaprecarity-deter-indonesians-from-getting-tested-for-covid-19. html. [Last accessed on 2020 Jul 14].

12. Dunn LB, Hammond KA, Roberts LW. Delaying care, avoiding stigma: Residents' attitudes toward obtaining personal health care. Acad Med. 2009;84:242-50. https://doi.org/10.1097/ acm.0b013e31819397e2

PMid: 19174679

13. Fischer LS, Mansergh G, Lynch J, Santibanez S. Addressing disease-related stigma during infectious disease outbreaks. Disaster Med Public Health Prep. 2019;13:989-94. https://doi. org/10.1017/dmp.2018.157 PMid:31156079

14. Djalante R, Lassa J, Setiamarga D, Sudjatma A, Indrawan M, Haryanto $\mathrm{B}$, et al. Review and analysis of current responses to COVID-19 in Indonesia: Period of January to March 2020. Prog Disaster Sci. 2020;6:100091. https://doi.org/10.1016/j. pdisas.2020.100091

15. Liao Q, Yuan J, Dong M, Yang L, Fielding R, Wing W, et al. Public engagement and government responsiveness in the communications about COVID-19 during the early epidemic stage in China: Infodemiology study on social media data. J Med Internet Res. 2020;22:e18796. https://doi.org/10.2196/18796 